\title{
EFFECT OF BAGASSE AS A ROUGHAGE SOURCE ON NUTRIENT DIGESTIBILTY, SOME BLOOD CONSTITUENTS AND GROWTH PERFORMANCE OF GROWING BEEF CROSSBREED CALVES
}

\author{
A.M. Singer ${ }^{1}$ and A. A. Marwan ${ }^{2}$ \\ ${ }^{1}$ Animal Production and Poultry Dept., Fac. of Agriculture and Natural Resources. Aswan Univ., Egypt. \\ ${ }^{2}$ Animal Production Dept., Fac. of Agric., Ain Shams Univ., Egypt. \\ *Corresponding author: Ahmed Marwan, ahmed_marwan97@yahoo.com
}

(Received 6/2/2019, accepted 27/3/2019)

\section{SUMMARY}

$\mathrm{T}$ This study was carried out to investigate the possibility different levels of a sun dried sugarcane bagasse (SDSCB) incorporation in growing beef crossbred calves (GBCC) as non-conventional source roughage under Aswan condition governorate as a partial replacement of barely straw in diet. Three experimental group of 54 animals each with initial live body weight of about 289 , 285.61 and $280.56 \mathrm{~kg}$ for $1^{\text {st }}, 2^{\text {nd }}$ and $3^{\text {rd }}$ group were used, respectively. Sun dried sugarcane bagasse (SDSCB) mash replaced $50 \%$ plus $1.5 \%$ urea and $100 \%$ plus $3 \%$ urea of the barely straw in three groups, respectively. The study was extended for fifteen weeks. Live body weights were individually recorded in all group. Blood samples were gathered from each animal in all groups at the finishing of study for determination of certain blood biochemical indices. Results showed that treated groups (T2 and T3) recorded significant increase $(\mathrm{P} \leq 0.05)$ in dry matter intake (DMI), digestion coefficients, average daily gain, total body weight gain and better feed conversion ratio in comparing with control group. Results showed a higher (P $\leq 0.05)$ water consumption recorded for animals fed bagasse plus urea in comparing with animals fed barely straw. Similar trend were detected in blood serum total protein, albumin, globulin, AST and ALT with a significant increase $(\mathrm{P} \leq 0.05)$ in the group fed the higher level of SDSCB in normal range. Economics of weight gain was also favorable $(\mathrm{P} \leq 0.05)$ for $100 \%$ bagasse plus $3 \%$ urea as compared to $0 \%$ bagasse group. In general, it may be concluded that SDSCB can be use in rations of growing beef crossbred calves (GBCC) up to the level of $100 \%$ of roughage diet.

Keywords: Sugarcane bagasse, crossbred calves, digestibility, biochemical profile, growth performance and economic efficiency.

\section{INTRODUCTION}

Integration of livestock production system with crop production has got great relevance for optimizing returns from the same land by way of getting additional revenue through the utilization of crop residues or agro-industrial by-products that are locally available with the farmer Venkata et al. (2018). Within this new scenario, it creates the need for more detailed nutritional information on the use of such waste in ruminant feed (Barros et al., 2009).

Costa et al. (2015) reported that one way to achieve this is the use of agro-products, but most of these foods have not been studied, and their compositions and appropriate concentrations for economic and biological use in animal production are not known. This leads to the need to study the feasibility of inclusion of several alternative food sources and quantify the responses of animal production.

The most important by products of sugarcane farming are sugarcane tops and sugarcane trash and those of industry are sugarcane bagasse, molasses, and sugarcane sludge and press mud Venkata et al. (2018). Bagasse is the term describing the fibrous residue of the sugarcane stalk after crushing and extraction of the juice. Bagasse is characterized as low quality feed for ruminants by virtue of its high content of ligno-cellulose, low crude protein (CP) and poor palatability (Brendt et al., 2002). On average, about 30 ton of wet (about 50\% moisture) sugar cane bagasse (SCB) is produced per 100 ton of sugar cane crushed per annum, and approximately $150 \mathrm{t}$ of dry bagasse per $100 \mathrm{t}$ of cane crushed is also produced per annum; so for every $3 \mathrm{~kg}$ of cane crushed, $1 \mathrm{~kg}$ of bagasse is produced. 
Bulle et al. (2002) emphasized that the use of bagasse from sugar cane in animal feed, on a commercial scale, has been poorly studied, leading to accumulation of large quantities in industry. This creates problems due to the lack of storage space and also reduce consumption by animals, since there may be contamination of the pulp by fungi and bacteria. Leme et al. (2003) evaluated different levels of inclusion of sugarcane bagasse in nature in diets of beef cattle confined with high levels of concentrate diets. They did not find out differences in performance between the different levels of inclusion of bagasse.

Sarmento et al. (2001) investigated the use of urea for improving the nutritive value of bagasse. They stated that bagasse can be incorporated with other locally available feed materials of high nutrient content for the formulation of a complete ration for improving its use by ruminants. Many researchers reported that sugarcane bagasse could be used as an exclusive source of roughage for beef cattle Leme et al. (2003).

In KOM OMBO center there is scarcity of roughage and the situation becomes worst in summer months. Rice straw, wheat straw and barley straw are the sources of roughages needed by farm animals as a roughage source. They are now facing rising prices due to their presence and increased demand. Therefore, those interested in animal feeding started looking for alternatives to traditional feed.

In Aswan governorate, principally in the Kom Ombo center, a big factory of sugar manufacturing are located with crushing capacities ranging from 1,000 to 7,000 M.T./day.

The objectives of this study were to view of the availability of bagasse in substantial quantities and at low cost, studies were undertaken to investigate the use of bagasse as ruminant feed replacement barely straw where its availability at low cost.

\section{MATERIALS AND METHODS}

Site of study:

This experiment was carried out at the farm of the Livestock Development Society in Kom Ombo belonged to Faculty of agriculture and natural resources ,Aswan University, Aswan Governorate ,Egypt, through the period from May 2016 to September 2016.

\section{The experimental animals and rations:}

Fifty four growing beef crossbred calves (GBCC), average live body weigh $285.05 \mathrm{~kg}$, randomly divided into three groups of similar weight and age. The first group T1 (control) took a diet containing $70 \%$ concentrates and $30 \%$ roughage (barley straw); The second group T2 were fed as T1 but we substituted $50 \%$ of the barley straw with $50 \%$ sun dried sugarcane bagasse plus $1.5 \%$ urea and the third group T3 were fed as T1 but $100 \%$ of the barley straw was replaced with $100 \%$ sun dried sugar cane bagasse plus $3 \%$ urea.

All animals kept under semi -open sheds from metals, while individually feeding system was applied. Minerals blocks and fresh water were available .Rations were offered as $2 \%$ of body weight concentrate and $1 \%$ of body weight roughage and residuals were daily weighed. During the experimental period, feed intake was daily weighed; while live body weight was biweekly determined before the morning feeding and feed allowance was adjusted accordingly.

Table (1): Chemical composition of the experimental feedstuffs and CFM(\% on DM basis).

\begin{tabular}{lllllllll}
\hline Feedstuff & DM & OM & CF & CP & EE & NFE & Ash & AIA** \\
\hline Bagasse & 92.12 & 95.68 & 31.76 & 2.86 & 0.80 & 60.26 & 4.32 & 10.47 \\
Barley straw & 90.84 & 82.37 & 49.62 & 4.01 & 2.03 & 26.71 & 17.63 & 14.38 \\
CFM* & 90.82 & 95.74 & 21.73 & 16.48 & 2.78 & 54.75 & 4.26 & 4.93 \\
\hline
\end{tabular}

* CFM: Concentrate feed mixture

**AIA: Acid insoluble ash

Sun dried Sugar cane bagasse (SDSCB) was collected from a local sugar mills. It was dried in sunlight for 3 days. The sun dried sugarcane bagasse was chopped and sieved to the desired particle size 
of about $3 \mathrm{~cm}$ and mixed with urea solution (1.5) and (3\%) for T1 and T2. Collection of sugar cane bagasse for small cow keepers is easily achieved because of the abundant family labour available but for larger units, this is a costly and labour intensive item (1 tons of SCB may be collected by one worker daily $=50 \mathrm{LE} / \mathrm{t}$ ). This partially solves the problem of collection and presents the material in a compacted form for easy storage. Chemical compositions of feed stuffs are illustrated in Table (1).

\section{Blood sampling and analysis:}

At the end of the experimental period blood samples were taken from five experimental growing beef crossbred calves (GBCC) randomly chosen from each group and left at refrigerator for 20 minutes, then centrifuged at 4000r.p.m for 15 minutes. Blood serum was separated and stored at $-20 \mathrm{c}$ until later analyses. Blood serum was determined for total protein (Armstrong and Carr, 1964), albumin (Doumas et $a l .$, 1971). AST, ALT (Reitman and Frankel, 1957) and globulin was calculated by difference.

\section{Feeding trails:}

Three experimental diets were conducted with different levels of sun dried sugarcane bagasse (SDSCB) in growing beef crossbred calves (GBCC). The first experiment used diet in mash form (containing $100 \%$ barely straw) while in the second experiment diets with $50 \%$ bagasse plus $1.5 \%$ urea and the third experiment diets with $100 \%$ bagasse plus $3 \%$ urea were offered.

The feeding trial of 105 days was conducted on growing beef crossbred calves (GBCC) at Kom Ombo Farm, Aswan. Fifty four male cross breed calves beef, which were selected and distributed randomly into three equal groups in randomized block design (RBD) considering live body weight. The experiment lasted for 105 days in addition to 7days for adaptation; Residual amount from the previous day were weighed to determine the amount consumed. Feed intake was calculated by subtracting feed residue from that offered in the previous day, and was averaged for the whole period. The live weight gain was calculated by subtracting the initial live body weight from the final one and divided by the experimental days. Then the feed conversion ratio was calculated by dividing the daily dry matter intake by the daily live weight gain $(\mathrm{kg} \mathrm{DM} / \mathrm{kg}$ gain).

\section{Digestibility trail:}

A digestibility trail was conducted for all the experimental calves using a grab sample method where acid insoluble ash (AIA) was used as an internal marker according to Schneider and Flatt (1975) for determining the nutrients digestibility. Fecal grab samples were collected handily at 8.0 a.m. and 2.0 p.m. for three successive days from each animal started from the 50th day of the experiment. Samples of rations offered and residuals if any were daily weighed during the collection period for further chemical analysis. Samples of feeds and faeces were analyzed for dry matter, crude protein, crude fiber, ether extract and ash content according to AOAC (1990).

\section{Economic efficiency:}

The economic efficiency was calculated according to the price of local market at the time of carrying out the experiment as follows: Economical efficiency $=(\mathrm{A}-\mathrm{B} / \mathrm{B}) \times 100$.

Where: $\mathrm{A}=$ Price of $\mathrm{kg}$ gain in Egyptian pounds B = Feed cost / kg gain in Egyptian pounds.

\section{Statistical analysis:}

Data were statistically analyzed by using SAS program (SAS, 2001) according to the following model. Yij $=\mu+\mathrm{Ti}+$ eij; Where: Yij $=$ the observation on the ith treatment, $\mu=$ Overall mean, $\mathrm{Ti}=$ Effect of the ith treatment and eij = Random treatment error. Duncan's Multiple Range test (Duncan, 1955) was also used for the comparison among means of the experimental treatments.

\section{RESULTS AND DISCUSSION}

\section{Dry matter intake:}

Data of dry matter intake (DMI) are reported in Table (2). There was no significant differences in feed quality indices between control and experimental rations. The DMI were higher $(\mathrm{P} \geq 0.05)$ in GCBC fed experimental rations compared to those fed control ration. The total DMI (Kg) values were 11.25, 11.35 
and 11.31 for $\mathrm{T} 1, \mathrm{~T} 2$ and $\mathrm{T} 3$, respectively. The highest values observed in the calves fed sun dried sugar cane bagasse (SDSCB).

Table (2): Effect of SDSCB on dry matter intake (kg/h/d) and water consumption.

\begin{tabular}{lccc}
\hline \multirow{2}{*}{ Period (days) } & \multicolumn{3}{c}{ Treatments } \\
\cline { 2 - 4 } & T1 & T2 & T3 \\
\hline $1-30$ & $10.12 \pm 0.17$ & $10.00 \pm 0.20$ & $9.81 \pm 0.20$ \\
$31-60$ & $10.85 \pm 0.17$ & $10.91 \pm 0.21$ & $10.76 \pm 0.21$ \\
$61-90$ & $11.62 \pm 0.17$ & $11.79 \pm 0.21$ & $11.77 \pm 0.22$ \\
$90-105$ & $12.41 \pm 0.18$ & $12.71 \pm 0.21$ & $12.88 \pm 0.22$ \\
Average & 11.25 & 11.35 & 11.31 \\
& & & \\
Water consumption $(1 / \mathrm{h} / \mathrm{d})$ & $43.72^{\mathrm{C}}$ & $64.39^{\mathrm{B}}$ & $73.97^{\mathrm{A}}$
\end{tabular}

$A, B$ and $C$ Means of treatments within the same row with different superscript letters are significantly different $(P \leq$ $0.05)$.

Similar results were reported by Geerjanand (2009) when he fed goats on bagasse based diet containing urea. Also, Venkata et al. (2018) recorded a positive increase on DMI in Lactating buffaloes with feeding sugarcane by-products based complete ration. Moreover, Mahala et al. (2013) on cross breed calves (Friesian x Kenana) pointed to an increase in DMI on calves fed bagasse based diet supplemented by urea.

Data in Table (2) showed that the higher DMI of SDSCB by treated animals may be attributed to the increased palatability and acceptability of the diet which reflect a better digestibility of nutrients and improved utilization of complete feed. Supplements can be considered as a means of increasing nutrient supply to animals that are unable to consume sufficient nutrients as forage (Romney et al., 2000).

Clean drinking water was made available for the GCBC and the volume per liter was measured per head daily $(1 / \mathrm{h} / \mathrm{d})$ in the period of 35 days duration, significantly $(\mathrm{P} \leq 0.05)$ higher water intake was observed in animals fed $100 \%$ bagasse plus $3 \%$ urea followed by $50 \%$ bagasse plus $1.5 \%$ as compared to the animals fed barely straw (table 2$)$. The data showed an increase $(\mathrm{P} \leq 0.05)$ in water consumption for groups fed ration plus SDSCB and urea (treated groups) than those of animals consumed ration plus barley straw (control group). This may be attributed to the effect of urea in roughage which require excessive desire to drink water in the animal to neutralize its effects.

\section{Nutrients Digestibility:}

Data of digestion coefficient of dietary treatments are presented in Table (3). Digestibility of DM, OM, $\mathrm{CP}, \mathrm{CF}, \mathrm{EE}$ and NFE were improved for animals fed SDSCB $(\mathrm{P} \leq 0.05)$ supplemented by urea as a roughage stuff (T2 and T3) than those fed barley straw as a roughage (T1). The best values of digestibility coefficient $(\mathrm{P} \leq 0.05)$ of the previous deferent nutrients were recorded in $\mathrm{T} 3$ followed by $\mathrm{T} 2$ (treated groups) and the lowest values were recorded in T1 (control group). The improved of nutrients digestibility with SDSCB plus 3\%urea may be due to increased ruminal cellulolytic microbial population

Table (3): Effect of SDSCB on the nutrients digestion coefficients.

\begin{tabular}{lccc}
\hline Item & $\mathrm{T} 1$ & $\mathrm{~T} 2$ & $\mathrm{~T} 3$ \\
\hline $\mathrm{DM}$ & $61.29^{\mathrm{C}} \pm 0.89$ & $69.19^{\mathrm{B}} \pm 0.74$ & $72.07^{\mathrm{A}} \pm 0.86$ \\
$\mathrm{OM}$ & $63.81^{\mathrm{C}} \pm 1.02$ & $71.97^{\mathrm{B}} \pm 1.18$ & $73.00^{\mathrm{A}} \pm 1.14$ \\
$\mathrm{CP}$ & $62.76^{\mathrm{C}} \pm 0.72$ & $64.39^{\mathrm{B}} \pm 0.68$ & $66.61^{\mathrm{A}} \pm 0.71$ \\
$\mathrm{CF}$ & $58.98^{\mathrm{C}} \pm 0.44$ & $62.23^{\mathrm{B}} \pm 1.08$ & $63.04^{\mathrm{A}} \pm 0.94$ \\
$\mathrm{EE}$ & $66.52^{\mathrm{C}} \pm 0.81$ & $68.85^{\mathrm{B}} \pm 0.92$ & $69.39^{\mathrm{A}} \pm 0.83$ \\
$\mathrm{NFE}$ & $69.48^{\mathrm{C}} \pm 1.07$ & $71.08^{\mathrm{B}} \pm 0.95$ & $73.07^{\mathrm{A}} \pm 1.41$
\end{tabular}

$\overline{A, B}$ and $C:$ Means of treatments within the same row with different superscript letters are significantly different $(P \leq$ 0.05). 
(Ghazanfar et al., 2015). The present data agreement with (Gunun et al., 2016) who found that use urea with sugarcane bagasse in ruminant's rations had positive effect on digestibility coefficients of different nutrients. Same results obtained by Geerjanand (2009) on goats fed bagasse based diet supplemented by urea.

\section{Blood metabolites:}

Data to study the effect of use Bagasse as substitutes of barely straw on some serum blood metabolites in growing crossbred beef calves are presented in Table (4). Blood serum total protein, albumin, concentration of calves at the end of experimental period were significantly increase $(\mathrm{P} \leq 0.05)$, while there were non-significant increase in globulin and $\mathrm{A} / \mathrm{G}$ ratio, although all values were in normal range (Kaneko et al., 1997). These results may be attributed that SDSCB plus urea enhance metabolic process as a response to increase apparent nutrients digestibility (table 3). In this connection, Kumar et al. (1980) and Bush (1991) reported that serum total proteins concentration reflects the nutritional grade of the animal and it has a great link with dietary protein level.

Concerning the indicators of liver functioning activity, AST and ALT values (table 4) were significantly increase $(\mathrm{P} \leq 0.05)$ by using SDSCB plus urea as a roughage source. The treated groups (T2 and T3) had the higher values $(\mathrm{P} \leq 0.05)$ in comparing with the control group (T1). These values were within normal physiological ranges (Kaneko et al., 1997).

The present values of AST and ALT activity indicate normal activity of the animal hepatic tissues, consequently, SDSCB with urea application in the present study had no an adverse effect on the liver activity.

Table (4): Effect of SDSCB on some serum biochemical parameters.

\begin{tabular}{lccc}
\hline Item & $\mathrm{T} 1$ & $\mathrm{~T} 2$ & $\mathrm{~T} 3$ \\
\hline Total protein $(\mathrm{g} / \mathrm{dl})$ & $7.08^{\mathrm{C}}$ & $7.27^{\mathrm{B}}$ & $7.53^{\mathrm{A}}$ \\
Albumin $(\mathrm{g} / \mathrm{dl})$ & $3.11^{\mathrm{B}}$ & $3.24^{\mathrm{B}}$ & $3.42^{\mathrm{A}}$ \\
Globulin $(\mathrm{g} / \mathrm{dl})$ & 3.96 & 4.03 & 4.11 \\
A/G ratio & 0.79 & 0.81 & 0.83 \\
AST (unit /L) & $66.40^{\mathrm{C}}$ & $67.27^{\mathrm{B}}$ & $69.12^{\mathrm{A}}$ \\
ALT (unit /L) & $56.78^{\mathrm{B}}$ & $68.04^{\mathrm{A}}$ & $69.78^{\mathrm{A}}$ \\
\hline
\end{tabular}

A, B and C Means of treatments within the same row with different superscript letters are significantly different $(\mathrm{P} \leq 0.05)$.

\section{Body weight and growth performance criteria:}

The average daily weight gain and growth performance of growing crossbred calves (GCBC) fed on different levels of sun dried sugarcane bagasse was presented in Table (5).

Data of Table $(5)$ showed higher significant $(\mathrm{P} \leq 0.05)$ total gain and daily gain values in treated groups (T2 and T3) than control (T1). The average daily gain (ADG) was higher $(\mathrm{P} \leq 0.05)$ in the treated groups (T2 and T3) that consumed ration containing SDSCB compared with T1 (control group).

It can be seen that the ADG was significantly $(\mathrm{P} \leq 0.05)$ higher for calves that consumed SDSCB than those consumed ration plus barley straw. Average daily weight gain for growing crossbred calves (GCBC) group were 0.933 and $0.859 \mathrm{~kg} /$ day for the tow treated groups (T2 and T3), respectively. This results were supported by Donovan (1979) who reported that the live weight gain for zebu bulls and steers was $0.79 \mathrm{~kg} /$ day. Also Ferreiro and Preston (1976) obtained average daily gain of $0.84 \mathrm{~kg}$ when Zebu bulls were fed sugarcane tops supplemented with rice polishing. But these values seem to be low when compared with finding of Lanna and Boin (1990) $0.91,0.87$ and $1.01 \mathrm{~kg}$ for three rations that contained, first basal diet contained grass-hay as a source of fiber, in the second and third diets grass hay was replaced by crude sugarcane bagasse and crude sugarcane bagasse with sodium bicarbonate, respectively, and Eltahir (1994) who found $1.36 \mathrm{~kg} /$ day. Magalhaes et al. (1999) found 0.52 and $0.45 \mathrm{~kg}$ gain per day for 20 and 30\% sugarcane tops, respectively. This might be due to large proportion of sugarcane tops which may increase the feed intake (yuangklang et al. (2005). Similar results was obtained by Geerjanand (2009) on goats and Mijinyawa et al. (2016) on red Sokoto bucks fed on diets based on sugarcane bagasse 
plus urea with or without enzyme supplementation, they found significant increase in total gain and average daily gain.

Table (5): Effect of SDSCB on changes of body weights and daily gain $(\mathrm{kg} / \mathrm{h} / \mathrm{d})$.

\begin{tabular}{|c|c|c|c|}
\hline \multirow{2}{*}{ Item } & \multicolumn{3}{|c|}{ Treatments } \\
\hline & $\mathrm{T} 1$ & $\mathrm{~T} 2$ & T3 \\
\hline \multicolumn{4}{|l|}{ Animal weight } \\
\hline Initial weight & $289.00 \pm 4.97$ & $285.61 \pm 5.82$ & $280.56 \pm 5.78$ \\
\hline Final weight & $362.77 \pm 5.25$ & $375.83 \pm 5.90$ & $379.11 \pm 6.30$ \\
\hline Total gain & $73.78^{\mathrm{C}} \pm 1.72$ & $90.22^{\mathrm{B}} \pm 0.70$ & $98.55^{\mathrm{A}} \pm 1.77$ \\
\hline Days & \multicolumn{3}{|c|}{ Average daily gain (kg/h/day) } \\
\hline $0-30$ & $0.637 \pm 0.03$ & $0.869 \pm 0.01$ & $0.933 \pm 0.02$ \\
\hline $31-60$ & $0.723 \pm 0.02$ & $0.844 \pm 0.01$ & $0.967 \pm 0.02$ \\
\hline $61-90$ & $0.756 \pm 0.04$ & $0.869 \pm 0.01$ & $1.05 \pm 0.01$ \\
\hline $90-105$ & $0.615 \pm 0.04$ & $0.854 \pm 0.04$ & $0.762 \pm 0.06$ \\
\hline Average & $0.683^{\mathrm{C}}$ & $0.859^{\mathrm{B}}$ & $0.933^{\mathrm{A}}$ \\
\hline
\end{tabular}

$A, B$ and $C$ Means of treatments within the same row with different superscript letters are significantly different $(P \leq$ 0.05).

\section{Feed conversion (kg DM/ kg gain):}

Data of Table (6) showed better dry matter conversion $(\mathrm{P} \leq 0.05)$ for groups consumed ration plus SDSCB (T2 and T3) in comparing with those consumed ration plus barley straw T1 (control group).

The feed conversion ratio was the best for $\mathrm{T} 3$ and difference was significant $(\mathrm{P} \leq 0.05)$. The FCR average for the T3, T2 and T1 are shown in Table (6) and it can be seen clearly that calves of T2 and T3 (treated groups) was better in both ADG and FCR than those of T1 (control group).

Feed conversion ratio for growing beef crossbred calves (GBCC) was found to be 14.99, 12.61 and 11.46 $\mathrm{kg} \mathrm{DM} / \mathrm{kg}$ gain for T1, T2 and T3, respectively. These results are in a good agreement with those obtained by Mahala et al. (2013) on cross breed calves (Friesian x Kenana). They noticed an increase in dry matter conversion on calves fed bagasse based diet supplemented by urea. On contrary, these findings were higher when compared with Magalhaes et al. (1999) findings 8.79 and $12.7 \mathrm{~kg}$ DM/kg gain for 20 and 30\% sugar-cane tops, This result disagreed with Elfadil (1995) who found the feed conversion ratio ranged from 13.87 to $20.2 \mathrm{~kg} \mathrm{DM} / \mathrm{kg}$ gain and Lanna and Boin (1990) who found 7.41, 7.24 and $7.03 \mathrm{~kg}$ $\mathrm{DM} / \mathrm{kg}$ gain. cross breed calves (Friesian $\mathrm{x}$ Kenana). They noticed an increase in dry matter conversion on calves fed bagasse based diet supplemented by urea. On contrary, these findings were higher when compared with Magalhaes et al. (1999) findings 8.79 and $12.7 \mathrm{~kg} \mathrm{DM} / \mathrm{kg}$ gain for 20 and $30 \%$ sugar-cane tops, This result disagreed with Elfadil (1995) who found the feed conversion ratio ranged from 13.87 to $20.2 \mathrm{~kg} \mathrm{DM} / \mathrm{kg}$ gain and Lanna and Boin (1990) who found 7.41, 7.24 and $7.03 \mathrm{~kg} \mathrm{DM} / \mathrm{kg}$ gain.

Table (6): Effect of SDSCB on dry matter conversion (kg DM/ kg gain).

\begin{tabular}{llll}
\hline Item & \multicolumn{1}{c}{ T1 } & \multicolumn{1}{c}{ T2 } & \multicolumn{1}{c}{ T3 } \\
\hline $1-30$ & $14.63 \pm 0.47$ & $11.52 \pm 0.23$ & $12.34 \pm 1.85$ \\
$31-60$ & $14.81 \pm 0.39$ & $12.94 \pm 0.24$ & $11.22 \pm 0.32$ \\
$61-90$ & $16.08 \pm 0.64$ & $13.60 \pm 0.27$ & $11.20 \pm 0.22$ \\
$90-105$ & $14.45 \pm 1.62$ & $12.38 \pm 0.72$ & $11.09 \pm 5.57$ \\
Average & $14.99^{\mathrm{A}}$ & $12.61^{\mathrm{B}}$ & $11.46^{\mathrm{B}}$ \\
\hline
\end{tabular}

$A$ and $B$ Means of treatments within the same row with different superscript letters are significantly different $(P \leq$ $0.05)$. 


\section{Economic efficiency:}

Results in Table (7) showed that, the lowest total feed cost/calf (2461.78 LE) was observed with crossbred calves fed $100 \%$ SDSCB plus $3 \%$ urea as a roughage source, followed by that fed 50\% SDSCB plus $1.5 \%$ urea and the one was the group fed barley straw as roughage source. Results also, revealed that groups fed the diets contained SDSCB were provided the highest economic efficiency (7.36 and 9.22) respectively, than the control group (6.50), which fed diets contained $100 \%$ barley straw as roughage source. Also, the relative economic efficiency was higher in groups fed on SDSCB plus urea (113.23 and 141.85) for T2 and T3 respectively, compared to the control group T1 (100).

Generally, it can be noticed that crossbred calves fed on the diets contained sun dried sugarcane bagasse (T2 and T3) had higher economic return than control group (fed 100\% barley straw). These results were in agreement with Geerjanand (2009) who fed goats on bagasse based diet plus urea.

Table (7): Effect of SDSCB on economic efficiency of growing rabbits.

\begin{tabular}{llll}
\hline Item & T1 & T2 & T3 \\
\hline Final weight & 362.77 & 375.83 & 379.11 \\
Price of 1 kg body weight & 60 & 60 & 60 \\
Selling price/calf (LE) A & 21766.20 & 22549.80 & 22746.60 \\
Total concentrate feed intake/kg & 918.75 & 927.15 & 924.00 \\
Total roughage intake/kg & 393.75 & 397.25 & 395.85 \\
Concentrate cost/LE & 2388.75 & 2410.59 & 2402.4 \\
Roughage cost/LE & 511.86 & 288 & 59.38 \\
Total feed cost/calf $(\mathrm{LE})(\mathrm{B})$ & 2900.61 & 2698.59 & 2461.78 \\
Net revenue (LE) $^{1}$ & 18865.59 & 19851.21 & 22687.22 \\
Economic efficiency $^{2}$ & 6.50 & 7.36 & 9.22 \\
Relative Econ. Eff. $^{3}$ & 100 & 113.23 & 141.85 \\
\hline
\end{tabular}

${ }^{1}$ Net revenue $=A-B$

${ }^{2}$ Economic efficiency $=(A-B / B)$.

${ }^{3}$ Relative Economic efficiency = Economic efficiency of treatments other than the control $/$ Economic efficiency of the control group.

\section{CONCLUSION}

The use of sugar cane bagasse in the ration of the crossbred calves showed an improvement in the voluntary intake and a remarkable increase in the digestibility coefficients. Also, SDSCB plus urea treated calves showed better daily weight gains, total weight gains and feed conversion rates. Therefore, inclusion complete diets for growing crossbred calves with SDSCB provided nutrients more than the recommended requirements with no opposing effects on liver function parameters.

Overall the results indicated that the treatment of bagasse with urea to form a mixed ration seemed to be beneficial compared with its performance as a single constituent.

\section{REFERENCES}

AOAC (1995). Association of Official Analytical Chemists. Official Methods of Analysis. 15th ed.. Arlongton, Virginiall USA.

Armstrong, W. D and C. W. Carr (1964). Physiological chemistry $3^{\text {rd }}$ ed. P, 75. Burges Publishing Co. Minneapolis, Minnesota. 


\section{Singer and Marwan}

Barros, R. C., V. R. Rocha Júnior and F. V. Silva (2009). Sugarcane or sugarcane bagasse ammoniated with urea replacing for sorghum silage for beef cattle in feedlot. Rev. Bras. Saúde Prod. An. 10(2):278-292.

Brendt, A., Henrique, Wignez, Lanna, Dante Pazzanese Duarte (2002). High ureacorn,sugarcane bagasse and corn silage in high concentrate diets :2. empty body chemical composition and tissues deposition rates. R.Bras. Zootec. 31 (5), 2105-2112. http://www.scielo.br/scielo.php. Acessed on April 2006.

Bulle, M. L. M., F. G. Ribeiro and P. R. Leme (2002). Performance of young bulls fed high concentrate diets with sugarcane bagasse as roughage source. Rev. Bras. Zootec. 31(1):444-450.

Bush, B.M. (1991). Interpretation of Laboratory Results for Small Animal Clinicians. Oxford Blackwell Scientific Publications, London.

Costa Dayana Alves; Clebson Lucas de Souza; Eloísa de Oliveira Simões Saliba and Jailton da Costa Carneiro (2015). By-products of sugar cane industry in ruminant nutrition. IJAAR 3 (2015) 1-9.

Donovan, O.P.B. (1979). Fattening crossbred and zebu cattle on local feeds and byproducts in Ethiopia World animal Review, 30: 23-29.

Doumas, B; W. Wabson and H. Biggs (1971). Albumin standards and measurement of serum with bromocresol green, clin. Chem..Acta., 31:87.

Duncan, D. B. (1955). Multiple range and multiple F test . Biometric, 11: 1-42

Elfadil, A.S. (1995). Effects of varying protein sources with high molasses/urea rations on fattening zebu calves. M.Sc. Thesis, University of Khartoum, Animal Production.

Elthair, I.C. (1994). Beef production potential of western Baggara and Friesian crossbred cattle. M.Sc. Thesis, Faculty of Animal Production, University of Khartoum.

Ferreiro, H.M and T.R. Preston (1976). Fattening cattle with sugarcane: The effect of different proportions of stalk and tops. Trop. Anim. Prod. 1: 178-185.

Geerjanand, Saraye (2009). Evaluating baggase based ration as a sole feed for goats. University of Mauritius research journal, V (15), 65-76.

Gunun, N ; M. Wanapat, ; P Gunun, ; A Cherdthong, ; P. Khejornsart and S. Kang (2016). Effect of treating sugarcane bagasse with urea and calcium hydroxide on feed intake, digestibility, and rumen fermentation in beef cattle. Tropical Animal Health and Production. V 48(6), 1123-1128.

Kaneko, J.J., J.W. Harvey and M.L. Bruss (1997). Clinical Biochemistry of Domestic Animals, 5th edn. Academic Press, San Diego, California, USA.

Kumar, N., U.B. Singh and D.N. Verma (1980). Effect of different levels of dietry protein and energyon growth of male buffalo calves. Ind. J. Anim. Sci., 15: 513-517.

Lanna, D.P.D. and C. Boin (1990). Effect of sodium bicarbonate, grass hay and untreated bagasse on the performance of growing zebu cattle fed on sugarcane bagasse treated with steam. Anaisde Escola superior de Agricultura Luizde Queiroz, 47: 2: 417-434.

Leme P. R., S. L.Silva, A. S. C.Pereira, S. M.Putrino, D. P. D. Lanna and J. C. M. Nogueira Filho (2003). Levels of sugarcane bagasse in diets with high concentrate for nellore steers in feedlot. R. Bras. Zootec. 32(6):1786-1791.

Magalhaes, L.R.G., H.M. Vasquez and J.F.C. da Silva (1999). Hydrolyzed sugarcane (Sacharum officinarum) bagasse and sugarcane tops associated with two protein sources in the fattening of feedlot steers. Revista-Brasileira-de-zootecnia, 28: 4, 822-830.

Mahala, A.G., A.M.S. Mokhtar, E.O. Amasiab and B.A. AttaElmnan (2013). Sugarcane tops as Animal Feed. International Research Journal of Agricultural Science and Soil Science, Vol. 3(4) pp. 147-151.

Mijinyawa, M. A., O. S. Lamidi, S. B.Abdu, H.Umar, H. A. Muhammad and A.G. Bala (2016). Effect of treated and untreated sugarcane bagasse with or without enzyme supplementation in total mixed ration on performance of red Sokoto bucks. J. Anim. Prod. Res. (2016) 28(2):150-160.

Romney, D.L. and M. Gill (2000). Intake of forage. In: Forage Evaluation in Ruminant Nutrition, pp 4357. (Eds D.I. Givens, E. Owen, R.F.E. Axford and H.M. Omed), CAB International, UK. 
Reitman, S. and S. Frankel (1957). Calorimetric method for the determination of serum glutamicoxaloacetic and glutamic- pyruvate transeaminase. An.J. Clin.Path. 28:56.

Sarmento, P., R.Garcia, A. J. V. Pires and A. S. Nascimento (2001). Soybean grain as urease source for the sugarcane bagasse ammoniation with urea. Scientia Agrícola. 58(2):223-227.

SAS (2001). Statistical Analysis System guide: Version 8.2th. Institute Inc. Cary. Nc. USA.

Schneider, B. H. and P. W. Flatt (1975). The evaluation of Feeds Through Digestibility Experiments The Univ. of Georgia Press Athens 30602.

Venkata, S.B. Pakala, R. Prasanna Kumar, M. Sahitya Rani and E. Raghava Rao (2018). Utilization of Sugarcane By-Products as Complete Rations for Milk Production in Buffaloes. Int.J.Curr.Microbiol.App.Sci (2018) 7(2): 3111-3117.

Yuanangklang, C., M.Wanapat and C.Wachirapakorn (2005). Effects of pelleted sugarcane tops on voluntary feed intake, digestibility and rumen fermentation in beef cattle Asian-australasian journal of animal sciences 18:(1) pp. 22-26.

تأثير استخدام مصاصة القصب كمصدر غذائي ماليء على القيمة الهضمية، بعض قياسات الدم و الأداء الإنتاجي في عجول اللحم الخليطة

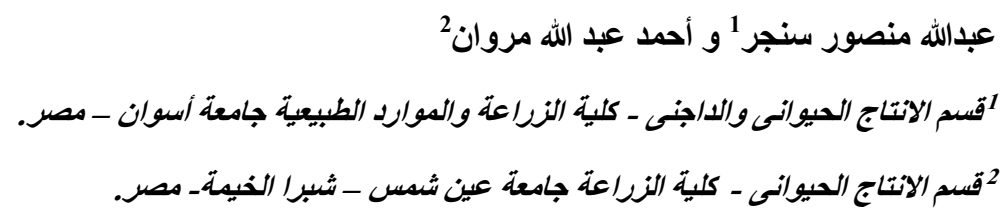

\footnotetext{
تهذف هذه الدر اسة إلى تقييم تأثثير استخدام مصاصة القصب المجففة شمسيًا والمضاف إليها يوريا في علائق عجول اللحم الخليطة

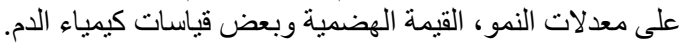

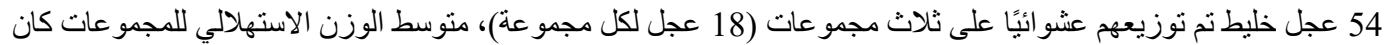

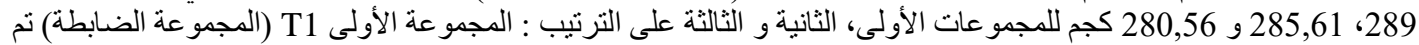

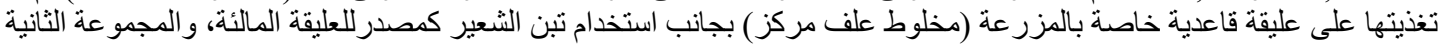

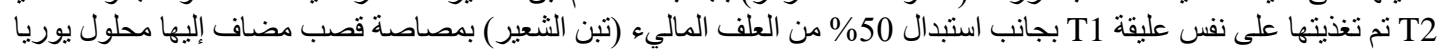

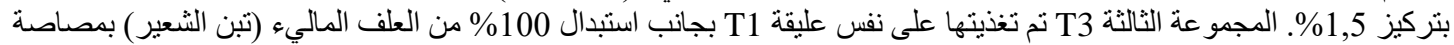

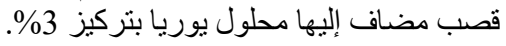

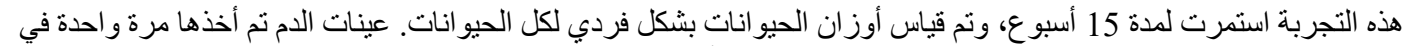

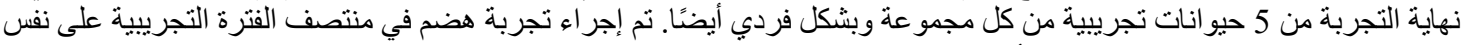
الخمسة عجول من كل مجمو عة الذين نم أخذ عينات دم منهم.

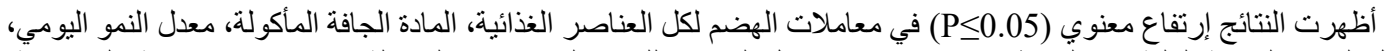

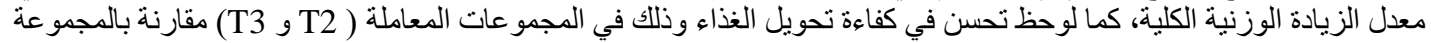

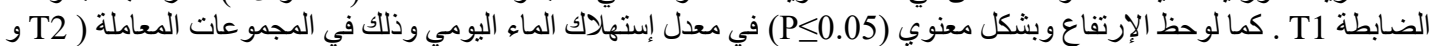

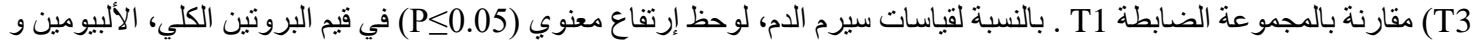

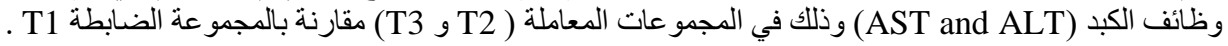

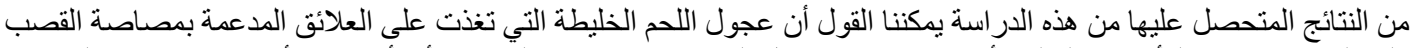

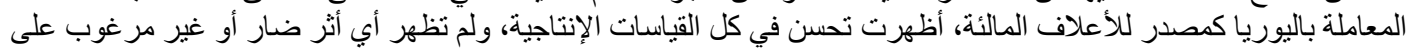
الحيو انات.
} 